VOX PATRUM 24 (2004) t. 46-47

Ks. Andrzej UCIECHA

(Katowice, UŚ)

\title{
POZYCJA SW. PIOTRA W PISMACH AFRAHATA I SW. EFREMA
}

\section{W MOWACH AFRAHATA}

Afrahat ( $†$ ok. 345) kilkakrotnie wspomina postać świętego Piotra w swoich Demonstrationes (= Mowach): $O$ wierze $^{1}, O$ pokutujacych ${ }^{2}, O$ pasterzach $^{3}$, $O$ obrzezaniu ${ }^{4}$ i $O$ winnym gronie ${ }^{5}$. Zawartą tam treść pobieżnie omówił J. Parisot $w$ introdukcji do ich krytycznego wydania ${ }^{6}$. Niecałe dziesięć lat później, w 1903 r. J. Parisot napisał artykul dla Dictionnaire de théologie catholique, poświęcony życiu i twórczości Afrahata, gdzie ponowił swoją opinię na temat pozycji i roli św. Piotra; zdaniem tego francuskiego tłumacza Mędrzec perski nazwał Apostoła „Księciem pasterzy”, na którym Chrystus założył swój Kościół; apostołowie Jan i Jakub są „mocnymi kolumnami Kościoła”, zaś Piotr jest „fundamentem" ${ }^{7}$. Należy wspomnieć, iż podobną opinię przedstawił F. Nau w 1924 r.; Kościół został założony na Piotrze, księciu pasterzy ${ }^{8}$. Stanowisko Nau'a wydaje się być bezkrytycznym powieleniem poglądów Parisota ${ }^{9}$.

${ }^{1}$ Por. Demonstratio 1 (De fide), 17, ed. J. Parisot: Aphraatis Sapientis Persae Demonstrationes, Paris 1894, PSyr 1, 40, $27-41,11$.

2 Por. Demonstratio 7 (De paenitentibus), 15, PSyr 1, 336, 17-22.

${ }^{3}$ Por. Demonstratio 10 (De pastoribus), 4, PSyr 1, 453, 7-11.

${ }^{4}$ Por. Demonstratio 11 (De circumcisione) 12, PSyr 1, 501, 22-26.

5 Por. Demonstratio 23 (De acino) 12, PSyr 2, 36, 5-12.

${ }^{6}$ Por. J. Parisot, PSyr 1, s. LIII: „Ecclesiam, e Gentibus collectam et promissionum haeredem effectam, ostendit, adsertor traditionis schismate antiquioris, super Petrum a Christo conditam [...], quem etiam vocat principem Pastorum".

${ }^{7}$ Por. tenże, Aphraate ou Pharhad, DThC I/2 1461: „Pierre est aussi le témoin fidèle posé au milieu des nations [...]; le <prince des pasteur> auxquels il a laissé la garde du troupeau [...]. Les apôtres Jean et Jacques sont <les collones tr\&egreve;s fortes de l'Église> mais Pierre en est le fondement".

${ }^{8}$ Por. F. Nau, Aphraate le Sage, DHGE III 937: „L'Église a été fondé sur Pierre, le prince des pasteurs".

${ }^{9}$ Kolejność omawianych kwestii oraz ich trešć zawarta w akapicie poświęconym doktrynie Afrahata wskazują, iż najprawdopodobniej Nau streścil opracowanie Parisota, por. Nau, Aphraate le Sage, DHGE III 937-938. 
W 1949 r. S.C. Williams zbadał stosowny tekst z Mowy o pasterzach i doszedł do wniosku, iż Parisot się myli1 ${ }^{10}$. Metodą analizy filologicznej i teologicznej udowodnil, że dla Afrahata to Chrystus byl przewodnikiem pasterzy i tylko jemu przysługuje tytuł głowy i naczelnika owczarni. Williams wykazał tam nadto brak spójności poglądów w opracowaniu Parisota, który w swoim Index Analyticus sam umieścił pięć referencji do Chrystusa jako Księcia pasterzy i żadnej do św. Piotra ${ }^{11}$.

Polemiczne opracowania omawianego problemu u obu autorów dzieli czas prawie półwiecza i przeciwne wnioski, do których doszli, łączy je zaś niezwykła lapidarność przeprowadzonych analiz. Można przypuszczać, że tak dla Parisota jak i Williamsa wydawało się czymś oczywistym i niepodważalnym to, co przedstawili; dla pierwszego dzieło Afrahata zawiera wyraźne potwierdzenie godności św. Piotra jako „Księcia Apostołów”, dla drugiego zaś tytuł ten przysługiwal w Mowach jedynie Chrystusowi. Wywody Williamsa oparte zostały na analizie lingwistyczno-teologicznej i dlatego jego argumentacja, chociaż krótka, jest zdecydowanie bardziej przekonywująca. Należy więc przyjąć, iż Afrahat przyznawał tytuł „Princeps pastorum” tylko Chrystusowi, a nie łączył go z osobą św. Piotra. Możliwe, że istnieje jeszcze inny powód tak rozbieżnych wniosków, do których doszli i których bronili Parisot i Williams. Wydaje się uzasadnione podejrzenie, iż badanie tematyki prymatu św. Piotra obciążone bylo presją doktrynalnych tendencji apologetycznych i polemicznych, w których obaj orientaliści żyli i tworzyli. Bezsprzecznie w taki właśnie sposób Parisot odczytywał i interpretował nauczanie Afrahata ${ }^{12}$.

1. Wiara św. Piotra. Wzmianki na temat św. Piotra znajdują się już w pierwszej Mowie Afrahata poświęconej zagadnieniu wiary ${ }^{13}$.

„Nasz Zbawiciel każdemu przychodzącemu do niego, aby zostać uzdrowionym również mówit: «Według wiary twojej niech ci się stanie» (Mt 9, 29). I gdy niewidomy zbliżył się do niego, rzekł mu: «Czy wierzysz, że mogę cię uzdrowic»? Ów

${ }^{10}$ Por. C.S.C. Williams, Aphraat on St. Peter, JTS 50 (1949) $71-72$.

11 Por. PSyr 2, 436-438.

12 Por. J. Parisot, Praefatio (Aphraatis doctrina 13), PSyr 1, s. LIII; zob. także: Aphraate ou Pharhad, DThC I/1 1459-1462.

${ }^{13} \mathrm{~W}$ akrostychicznej strukturze Mów Afrahata zagadnienie wiary omówione zostało jako pierwsze, ze wskazaniem również jej owoców, por. Demonstratio 1, 18, PSyr 1, 41, 23 - 43, 12: „W ten sposób, mój drogi, zbliżamy się do wiary, która tak wielką moc posiada. Wiara bowiem aż do nieba wyrasta, ona pokonała powódź, pomogla urodzić niepłodnej, wybawiła od miecza, wyprowadziła ze studni, uczyniła biednych bogatymi, wyzwoliła więźniów, uwolniła prześladowanych, stłumiła ogień, rozdzieliła morze, przedziurawiła skałę, nasyciła pragnienie spragnionych, nakarmiła głodnych, wskrzesiła zmarlych, wyprowadziła z Szeolu, uciszyla fale, przywróciła zdrowie chorym, pokonała wojska, zburzyła mury, zamknęła paszcze lwów, ugasiła płomień ognia, poniżyła pysznych, doprowadziła do chwały pokornych: te wszystkie cuda przez wiarę zostały uczynione (por. Hor 11, 32-35)". 
niewidomy odparł mu: «Tak, mój Panie, wierzę» (Mt 9, 28-29). Jego wiara przywróciła wzrok jego oczom ${ }^{14}$. Do tego, którego syn chorowal, powiedzial: «Wierz a żyć będzie twój syn». Odparł mu: «Wierzę, mój Panie, wspomóż moją słabą wiarę» (Mk 9,24). I dzięki jego wierze wrócil do zdrowia jego syn. Także przez wiarę zbliżył się do niego sługa królewski i uzdrowione zostało jego dziecko. Powiedział wtedy do naszego Pana: «Rzeknij tylko slowo, a uzdrowione będzie moje dziecko» (Mt 8, 8-10; Łk 7, 1-10). Zadziwił się Pan jego wiarą i według jego wiary mu uczynit. Podobnie powiedział przełożonemu synagogi, który prosił go za swoją córką: «Jedynie wierz mocno, a żyć będzie twoja córka» (Mt 9, 18-19. 23-26; Mk 5, 22-23. 35-42). Uwierzył i ożyła jego córka, i wstała. Gdy zmarł Łazarz, rzekł Pan do Marty: «Jeśli wierzysz powstanie brat twój». Odparla mu Marta: «Tak, mój Panie, wierzę» (J 11, 23-27). I wskrzesił go po czterech dniach. Także Szymon, zwany Piotrem, nazwany został niewzruszoną skałą dzięki swojej wierze (por. Mt 16, 18)"15.

Mędrzec perski wymienił pięć przykładów ilustrujących postawę wiary godną naśladowania (niewidomy pod Jerychem, ojciec chlopca chorego na epilepsję, setnik z Kafarnaum, Jair, Marta siostra Łazarza). Wszystkie te wzorce zostały zaczerpnięte $z$ Ewangelii. Zamieszczona po nich krótka wzmianka (szósty przykład) podkreśla wiarę Szymona Piotra, dzięki której nazwany został „niewzruszoną skałą". Znamienne, że przykład Apostoła został podany na koniec tego paranetycznego fragmentu. Można byłoby przypuszczać, iż akcentowanie wiary Piotra stanowi zwieńczenie wcześniej podanych przykładów. Afrahat z pewnością miał taki zamiar, ale nie poprzestał na chwaleniu Apostoła i zaraz ukazał słabość jego wiary.

„Gdy Pan przekazał swoim uczniom sakrament chrztu, tak im rzekt: «Kto uwierzy i ochrzci się, będzie żyl, a kto nie uwierzy, zostanie osądzony» (Mk 16, 16). Podobnie powiedział swoim uczniom: «Jeśli uwierzycie i nie zwątpicie, nie będzie niczego, czego nie moglibyście uczynić» (Mt 21, 22). Gdy zaś Pan maszerował po falach morskich, również Szymon przez swoją wiarę maszerował z nim. Gdy jednak zwątpił w wierze, zaczął tonąć, a Pan krzyknąl: «Małej wiary» (Mt 14, 31). Gdy uczniowie prosili o coś Pana, niczego od niego nie żądali, jedynie mówili mu: «Przymnóż nam wiary». Odparł im: «Jeśli będziecie mieć wiarę, nawet góra odejdzie sprzed waszego oblicza» (Mt 17, 20; Mk 11, 22-23; Łk 17, 5). Rzekł do nich: «Nie ulegajcie zwątpieniu pośród tego świata, jak Szymon, gdy zwątpił i zaczął tonąć w morzu» (Mt 14, 28-31). Powiedzial jeszcze tak: «Dla tych, co uwierzą, taki znak będzie: nowymi językami mówić będą, demony wyrzucać będą, swoje ręce kłaść będą na chorych, a ci będą uzdrowieni» (Mk 16, 17-18)"16.

Szymon Piotr, który jako pierwszy wyznał wiarę w Syna Bożego i nie bał się chodzić po wodzie, powinien stanowić wzór do naśladowania, równocześnie

${ }^{14}$ Według Mt 9, 27nn Jezus spotyka dwóch niewidomych, według Mk 10, 46nn i Łk 18, 35nn uzdrowiony zostaje jeden niewidomy. W Mk 10, 46 wspomniane jest nawet jego imię Bartymeusz, syn Tymeusza.

15 Demonstratio 1, 17, P Syr 1, 40, 5-41, 1.

16 Tamże, PSyr 1, 41, 2-22. 
jednak świadectwo jego niewiary, pełni funkcję przestrogi przed niebezpieczeństwem zwątpienia. Warto tu zaznaczyć, że Mędrzec perski nie wspomina nigdzie w Mowach o ostrej reprymendzie, której Jezus udzielił Szymonowi, gdy ten nie chciał pogodzić się z Jego męką i śmiercią (por. Mt 16,21 - 23).

W Mowie o pokutujących Afrahat nawiązał do osoby św. Piotra w kontekście skruchy ucznia, który wyparł się swojego Mistrza:

„Wy, którzy błagacie o nawrócenie, bądźcie podobni do Aarona, przywódcy kapłanów: gdy nakłonil lud do grzechu przez cielca, uznał swój grzech i jego Pan wybaczył mu (por. Wj 32,21-24). Również Dawid, najwyższy z królów Izraela (Parisot: „summus ex regibus Israel”), uznał swój grzech i zostało mu to wybaczone (por. 2Sm 12, 13). I Szymon, który stał na czele uczniów (Parisot: „princeps discipulorum"), a który zaprzeczył, że widział Chrystusa, zaklinał się przysięgając: «Nie znam go» (Mt 26, 74); gdy skrucha przyszła na niego, przelał wiele łez (por. Mt 26, 75). Nasz Pan przyjął go i uczynił go fundamentem (Parisot: „posuit eum in fundamentum"), oraz nazwal go skałą i budowlą Kościoła (por. Mt 16,18)"17.

Zdrada św. Piotra i jego nawrócenie ukazane tu zostały na tle wybitnych postaci Starego Testamentu: arcykapłana Aarona i króla Dawida. Przywołanie tych biblijnych wydarzeń posiadało niewątpliwie aspekt parenetyczny i miało zachęcić adresatów Mowy do pokuty i pojednania ${ }^{18}$. Wydaje się, iż nie było przypadkowe umieszczenie osoby Piotra w kontekście tych wybitnych, chociaż nie bezgrzesznych, postaci $z$ historii Starego Testamentu. Należy zaznaczyć, iż Afrahat nie zapomniał też o nawróceniu innego z wielkich Apostołów św. Pawła, równie godnego naśladowania dla wszystkich pokutujących ${ }^{19}$, przy nim jednak wskazał wzór św. Piotra.

2. Służba pasterska św. Piotra. W Mowie o pasterzach Mędrzec perski starał się naszkicować obraz idealnego pasterza. W tym celu przedstawił najpierw sylwetki sprawiedliwych mężów Starego Testamentu (Jakub, Józef, Mojżesz, Dawid, Amos), następnie zacytował obszerny fragment mowy przeciwko złym pasterzom z proroka Ezechiela (por. Ez 34, 1-31), a w końcu przytoczył słowa samego Chrystusa z Ewangelii według św. Jana:

„«Dobry pasterz daje duszę swoją za owce swoje» (J 10,11). I dodał: «Mam jeszcze inne owce i muszę je przyprowadzić tutaj, i będzie jedna cała owczarnia i jeden pasterz. Dlatego Ojciec mój miłuje mnie, ponieważ duszę swoją daję za owce» (J 10, 16-17). Powiedział jeszcze: «Ja jestem bramą owiec. Każdy, kto wejdzie przeze Mnie będzie żył: wejdzie i wyjdzie, i znajdzie paszę» (J 10, 9). O, pasterze! Starajcie się upodobnić do tego gorliwego Pasterza, naczelnika całej owczarni,

17 Demonstratio 7, 15, PSyr 1, 336, 12-22.

${ }^{18}$ Najprawdopodobniej bezpośrednimi adresatami Mowy o pokutujących byli ci „synowie przymierza”, którzy złamali złożoną przysięgę czystości, por. A.Uciecha, Rola i miejsce „synów przymierza" w Kościele perskim $I V$ w. (na przykładzie Mów Afrahata), VoxP 22 (2002), t. 42-43, 161-175.

19 Demonstratio 7, 23, PSyr 352, 27. 
który tak bardzo troszczył się o swoje stado. Przybliżył tych, którzy byli daleko; sprowadzil z powrotem tych, którzy zabłądzili; otoczył troską chorych i wzmocnił osłabionych, obwiązal złamane i strzegł tlustych; wydał samego siebie za owce. Wybrał i pouczył znakomitych pasterzy i oddał owce w ich ręce, i dał im władzę nad całą swoją owczarnią. Powiedział bowiem do Szymona Piotra: «Paś owce moje, baranki moje i moje owieczki» (J 21, 15-17). I Szymon pasł jego owce. A gdy jego czas się wypełnił, wam powierzył całą owczarnię i odszedł. Paście ją i wy, i prowadźcie dobrze! Pasterz, który troszczy się o swoje owce, nie może wykonywać innego zajęcia: nie sadzi winorośli, ani nie buduje ogrodów, aby nie wpaść $w$ troski tego świata. Nigdy nie widzimy pasterza, który zostawiłby swoje owce na polu, aby stać się kupcem, albo pozwoliłby bląkać się swojemu stadu, aby on mógl być oraczem. Jeśli bowiem pozostawia swoje stado, aby takie zajęcia wykonywać, wydaje swoje owczarnię wilkom"20.

To właśnie na podstawie tłumaczenia tego fragmentu Parisot nazwał (błędnie zdaniem S.C. Williamsa) św. Piotra „princeps totius gregis”. W rzeczywistości określenie to wyraźnie wskazuje na samego Chrystusa, który deleguje swoich następców, powierzając im władzę i zadanie prowadzenia społeczności wiernych. Możliwe, iż Parisot zasugerował się tutaj przydomkiem „princeps discipulorum", którego Afrahat użył na określenie św. Piotra w Mowie o pokutujących. Trudno jednak usprawiedliwić błąd pomieszania i zamiennego traktowania terminów „książę całej owczarni” i „książę uczniów”.

3. Świadectwo św. Piotra. W Mowie o obrzezaniu Mędrzec perski ukazuje Szymona w typowej dla siebie egzegezie typologicznej:

„Jozue, syn Nuna, ustawił kamienie na świadectwo w Izraelu (Joz 4, 20-24). Jezus, nasz Zbawiciel, nazwał Szymona prawdziwą skałą i ustanowił go świadkiem wiernym pośród narodów"21.

Nazwanie i ustanowienie przez Chrystusa stanowią istotę misji św. Piotra; podobnie jak kamienie ułożone przez Jozuego, Szymon, zwany „skała”, przeznaczony został na Bożego świadka. Jego świadectwo urzeczywistnia się wśród narodów, co w Mowach znaczy - wśród pogan.

W swojej ostatniej interesującej nas mowie $O$ winnym krzewie Afrahat nawiązuje do osoby Piotra $w$ analizie przymierza zawartego $z$ Mojżeszem i Chrystusem:

„[Jezus] potwierdził nam obietnicę, że my będziemy z Nim; zaś swoim apostołom, którzy Go prosili, ukazał zawczasu znak Jego przyjścia, gdy wziął swoich trzech uczniów Szymona, Jakuba i Jana: Szymona Piotra - fundament Kościoła, Jakuba i Jana - trwałe kolumny Kościoła"22.

${ }^{20}$ Demonstratio 10, 4, PSyr 1, 452, $17-453,19$.

21 Demonstratio 11, 12, PSyr 1, 501, 22-26.

22 Demonstratio 23 (De acino), 12, PSyr 2, 36, 5-12. 
Obowiązek świadectwa, jako nieuchronnej konsekwencji spotkania z Bogiem, nie pojawia się tutaj wprost, zaś wyjątkowa pozycja niektórych apostołów, w tym Piotra, wynika $z$ dopuszczenia ich do tych tajemnic Boga, do których inni nie mieli dostępu.

\section{W PISMACH ŚW. EFREMA}

W prolegomenie do starej krytycznej edycji Hymnów i kazań św. Efrema $(† 373)$ T.J. Lamy podkreśla najważniejsze punkty Sermo IV: „Antiquissimum hoc est Ecclesiae Syriacae testimonium de primatu Petri. Ita autem clara et aperta sunt Ephraemi verba, ut clariora non occurrant apud Patres latinos aut graecos" 23 . Następnie wydawca ten podał krótką analizę wybranych fragmentów z dzieł Efrema, które miałyby wyraźnie świadczyć o prymacie św. Piotra ${ }^{24}$. Należy tu postawić pytanie, czy w odkrywaniu i interpretowaniu teologii św. Efrema Lamy nie uległ presji poprawności apologetycznej, podobnie jak Parisot i Williams w analizowaniu nauczania Afrahata. Omawiając temat pozycji św. Piotra w dziełach Efrema należy wspomnieć opracowanie Raphaela Chaba z 1960 roku. Ten syryjski kapłan skupił się na omówieniu argumentu patrystycznego w kontekście rozumienia prymatu Piotrowego w syryjskim Kościele Jakobitów ${ }^{25}$. Wydaje się jednak, iż w przyczynku Chaby zbyt pobieżnie potraktowano materiał źródłowy.

Efrem Syryjczyk mówi o świętym Piotrze w kilku miejscach swoich hymnów i kazań ${ }^{26}$ oraz w dziele $O$ dziewictwie ${ }^{27}$, i nazywa go, używając przy tym m.in. takich określeń, jak: „głowa naszego nauczania”"28, „Książę Apostołów”29, „fundament Kościoła świętego" ${ }^{30}$, „głowa uczniów”31. Co ciekawe, gdy jednak Syryjczyk analizuje w dłuższym wywodzie scenę umycia nóg Apostołów w Wieczerniku, to ukazuje niewiedzę i pokorę Piotra, bez używania jakichkolwiek terminów podkreślających jego wyjątkowość ${ }^{32}$. Już pobieżna

${ }^{23}$ Por. Sancti Ephraemi Syri hymni et sermones. Prolegomena, ed. T.J. Lamy, I, Mechliniae 1882, s. LXXIV.

${ }^{24}$ Por. tamże, s. LXXV: „Alia de Petri primatu in eodem codice et in aliis codicibus Ephraemo tribuuntur".

25 Por. R. Chaba, La primauté de Pierre et du pape dans l'Église syrienne orthodoxe, w: Il primato e l'unione delle chiese nel Medio Oriente, Studia Orientalia Christiana. Collectanea V, Cairo 1960, 183-214.

${ }^{26}$ Por. S. Ephremi Syri hymni et sermones, ed. et trad. T.J. Lamy (= LA), I-IV, Mechliniae 1882, 1886, 1889, 1908.

27 Por. E. Rahmani (ed.), St. Ephraem, De virginitate, Charfe 1906.

28 Sermo in Hebdomadam Sanctam V, LA I 435, 7.

29 Tamze, LA I 435, 13 i 437, 1.

30 Sermo in Hebdomadam Sanctam IV, LA I 412, 8.

31 Hymni dispersi III 1, LA IV 681.

32 Por. Sermo in Hebdomadam Sanctam III, LA I 393-397. 
analiza tych podanych określeń pozwala stwierdzić, iż Efrem więcej uwagi poświęcił pozycji świętego Piotra niż Afrahat.

1. Piotr fundamentem Kościoła. Najpierw Efrem wyjaśnia znaczenie i konsekwencje nowego imienia nadanego Szymonowi przez Jezusa:

„Błogoslawiony jesteś, Piotrze, bo Syn Boży postawił cię na fundamencie Kościoła, abyś podtrzymywał ciężar całego stworzenia, jak On podtrzymuje cały świat. Przez pewnosć twojego wyznania uciszyły się wezbrane fale kłótliwych mędrków [...]. Błogosławiony jesteś, bo postawiono cię, abyś zaopiekował się i zajął wszystkimi stanami ludzi: abyś stał się bliźnim tak dla sprawiedliwych jak i dla grzeszników. Wśród wybranych jesteś dzielny i [najbardziej] zdatny; wśród grzeszników jesteś tym, który odrzuca godności; jesteś towarzyszem upadłych, ponieważ czyniłeś pokutę i podniosłeś tego, który upadł. Błogosławiony jesteś ty, którego [Pan] wezwał do siebie, krocząc morskimi ścieżkami na falach (por. Mt 14,28). Zachwyt twojej miłości ogarnął cię, abyś spieszył drogą, która cię nigdy nie znużyła. $\mathrm{Z}$ radością zostawileś łódź i szczęśliwy pospieszyłeś do swojego Pana [...]. Błogosławiony jestes, Szymonie, ponieważ na tobie zbudowany jest Kościół, piękna oblubienica światła, której Syn Boży obiecal, że bramy piekieł jej nie przemogą"33.

U podstaw Kościoła leży więc wiara św. Piotra; to ona pomaga rozpoznać i wybrać prawdę, i to dzięki niej Kościół może ogarnąć swoim działaniem wszystkich ludzi, zwłaszcza grzeszników.

Chrystusowa nominacja Szymona jako podstawy Kościoła związana jest z obowiązkiem obrony tej budowli:

„Ciebie, Szymonie, mój uczniu, ustanowilem fundamentem Kościoła świętego. Nazwałem cię «skałą" od początku, abyś podtrzymywal całą budowlę. Ty jesteś egzaminatorem tych, którzy budują mi Kościól na ziemi. Jeśli stawiają coś złego, twój fundament ich powstrzyma" ${ }^{34}$.

Eklezjologiczny dynamizm Piotrowej posługi wyraża się w posłudze rozróżniania tego, co dobre i tego co złe. To zadanie gwarantuje skuteczność konstruktywnego budowania Kościoła. „Fundament Kościoła” zapewnia stabilność całej budowli [również] przez to, iż ocenia jakość pracy budowniczych. Weryfikacja sposobu budowania wpisana jest w zakres obowiązków apostoła ustanowionego podstawą Kościoła.

2. Piotr glową Kościoła. Podobnie jak Chrystus, św. Piotr stanowi fundament i glowę Kościoła:

„Ty jesteś głową - źródłem mojej nauki; ty jesteś głową moich uczniów. Przez ciebie napoję wszystkie ludy. Dla ciebie ożywcza słodycz, którą daję. Ty jesteś

${ }^{33}$ Hymni dispersi III 7-12, LA IV 685-687.

34 Sermo $I V$ in Hebdomadam Sanctam 1, LA I 411. 
tym, którego wybrałem jako pierworodnego mojej nauki, abyś był dziedzicem moich skarbów. I tobie dałem klucze mojego Królestwa. Oto dałem ci władzę nad wszystkimi moimi ukrytymi skarbami" ${ }^{35}$.

Kolejnym więc chrystologicznym obrazem, który Efrem przenosi na postać Szymona Piotra, jest głowa. W pojęciu tym ukryte zostało przekonanie o Piotrowym posiadaniu prawdy i przywileju pierwszeństwa w gronie Apostołów. Określony mianem "pierworodny”, św. Piotr wyznaczony został na dziedzica i obrońcę prawdy. Syryjczyk wyraźnie akcentuje społeczny charakter pozycji Szymona:

„Błogosławiony jesteś, bo stałeś się jakby głową i głosem (językiem) ciała twoich współbraci; ciała złożonego z uczniów. Synowie Zebedeusza stali się dla ciebie jakby oczami. Blogosławieni oboje, którzy domagali się tronów od swojego Mistrza, ponieważ ujrzeli Jego tron (por. Mt 20, 20-23). Szymon usłyszał objawienie od Ojca, skała niewzruszona" ${ }^{36}$.

Jako głowa Apostołów Piotr posiada władzę zabierania głosu w ich imieniu.

3. Piotr pasterzem owiec. Piotr naśladuje Chrystusa jako pasterza owiec:

„Błogosławiony jesteś, bo Syn Boży uczynil cię pasterzem swojej trzody [...] i powiodłeś stado Syna Bożego do życiodajnych źródeł. Błogosławiony Kościól, który raduje się Jego napojem, i jego dzieci, które gaszą pragnienie w Jego strumieniu. Błogosławione twoje stado, prawdziwy pasterzu, spragnione twojej bliskości. Błogosławiony jesteś, bo zamiast łowienia ryb zagarniasz ludzi dla życia; twoja wiara jest jak wielka sieć. Zabite Ciało jest pełne życia. Przez krzyż wszystkie ludy zostały złowione i zebrane do Bożej sieci, do tej [sieci], którą niosłeś, błogosławiony uczniu. I w niej rosła twoja chwała" ${ }^{37}$.

Piotr pełni obowiązki pasterza owiec, które należą do Chrystusa, nie jest więc właścicielem stada, lecz jego zarządcą. W sensie ścisłym tytuł pasterza owiec przysługuje Chrystusowi, Piotr zaś jest Jego pełnomocnikiem ${ }^{38}$.

${ }^{35}$ Tamże, LA I 411; por. Hymni dispersi III, 1-3, LA IV 681-683: „Błogosławiony jestes, Szymonie, glowo uczniów, bo Syn Boży nazwał cię błogosławionym, i uczynil cię zarządcą swojego skarbca, i dał ci klucze Królestwa i władzę nad swoimi niebieskimi dobrami, i z milością wprowadzil cię do domu swego Ojca, i staleś się przyjacielem, bliskim i miłośnikiem ludzi. Błogosławiony jesteś, bo wybrał cię Syn Boży i uczynił głową dla uczniów. Dał ci moc i wladzę zawiązywania i rozwiązywania mocą Bożą, u bram swojego skarbca cię postawił, abyś zarządzal boskimi łaskami; ponad wszystko cię wywyższyl, a w niebie i na ziemi rozciągnąl twoją władzę. Blogosławiony jesteś Szymonie, ponieważ Ojciec objawil ci tajemnicę swojego Syna".

${ }^{36}$ Hymni de Ecclesia et virginitate XV 8, LA IV 533; De virginitate, ed. E. Rahmani, s. 46: „Błogosławiony jesteś, bo stałeś się jakby glową i glosem [dosł. językiem] ciała twoich wspólbraci; ciała złożonego z Dwunastu".

${ }^{37}$ Hymni dispersi III 2-6, LA IV 683-685.

${ }^{38}$ Hymnus $V$ de Abraham Kidunaia 13, LA III, 783: „Właściciel owiec, który karmil się pożywieniem pasterzy, powierzył swoje stado Szymonowi, który mu się podporządkował. Powta- 
4. Piotr klucznikiem. Chrystus przekazał Piotrowi klucze królestwa niebieskiego (por. Mt 16,19).

„Błogosławiony jesteś, Szymonie Piotrze! Ty trzymasz klucze, które Duch sporządzil. Wielkie i niewypowiedziane jest słowo, które wiąże i rozwiązuje to, co w niebiosach, i to, co na ziemi. Blogosławione stado, które ci dano, niech rośnie!"39.

Efrem poszerza tu refleksję nad przekazaniem Piotrowi władzy wiązania i rozwiązywania o wątek pneumatologiczny. Zadanie podejmowania właściwych decyzji na podstawie tego przywileju przekracza ludzkie możliwości, stąd potrzebna jest asystencja Ducha Świętego: to On jest twórcą władzy kluczy. Także i w tej myśli Syryjczyk zawarł ideę pośrednictwa Piotrowej posługi i władzy.

5. Piotr przykładem świętości. Efrem, opisując przygotowania Jezusa do ostatniej Paschy (por. Łk 22, 8), podkreśla świętość Piotra:

„[Jezus] wezwal Szymona i Jana, dwóch swoich przyjació: świętą głowę apostolów, skałę-fundament Kościoła, i czystego w dziewictwie [ucznia], na którym wzniósł i zwieńczył swoją budowlę; świętego Szymona postawił jako dopełnienie wielkiego Mojżesza, zaś syna Zebedeusza postawił jako następcę Jozuego, syna Nuna. Wysłał dziewictwo i świętość, aby Mu przygotowały Paschę; uznał bowiem ich obu, fundament i ornament, godnych, aby rozpoczęli święte Tajemnice. I wspaniałe bogactwa wszelkiego rodzaju przygotowane zostały przez budowniczych pałaców w ich budowlach. Blogosławione jesteście kobiety, które urodziłyście Szymona i Jana, bo wasze dzieci osiągną najwyższe niebo!"40.

Efrem nazywa tu Piotra już nie głową, ale „świętą" głową apostołów, jest on bowiem typem Mojżesza, który symbolizował ideał świętości. W ascezie syryjskiej IV wieku atrybut „święty” stał się technicznym określeniem tego, który będąc żonaty zrezygnował dla Boga z małżeństwa ${ }^{41}$.

Wyjątkowa pozycja świętego Piotra wynika według Afrahata i św. Efrema $\mathrm{z}$ ciążącej na nim odpowiedzialności; został obarczony zadaniem czuwania, aby

rzal trzykrotnie, aby ostrzec, otrzymał trzy obietnice Pasterza: paść baranki z milością, traktować owce z czulością, strzec owce z bojaźnią".

${ }^{39}$ De virginitate hymnus 15, 6, ed. E. Beck, CSCO 223, PSyr 94, 53; Hymni de Ecclesia et virginitate XV 7, LA IV 533; por. Hymni dispersi III 5, LA IV 683: „Błogoslawiony jestes, Szymonie, bo otrzymałeś klucze, które Duch Święty uformowal".

40 Sermo II in Hebdomadam Sanctam 4, LA I 374, 3-18.

41 Kojarzenie Mojżesza ze świętością, a Jozuego $z$ dziewictwem, występuje także w Mowie o świętości Afrahata. Rozróżnienie, jakiego tam dokonal Mędrzec perski, miało na celu ukazanie różnych grup istniejacych w lonie bezżennych „synów przymierza”, por. A. Uciecha, Ascetyczna nauka w ,Mowach" Afrahata, Katowice 2002, 31-32. 
Kościół budowany był na prawdzie. Funkcja fundamentu nie ogranicza się tylko do statycznego podtrzymywania całej budowli, ale obejmuje też obowiązek rozróżniania fałszu i prawdy. Nadto Piotr otrzymał zadanie kierowania gronem Apostołów, reprezentowania ich oraz prowadzenia Kościoła; dana mu została władza pośredniczenia między Bogiem a ludźmi, pieczętująca jego decyzje boskim autorytetem i uzasadniona asystencją Ducha Swiętego. Piotr został ukazany jako wzór świętości, co dla Efrema najprawdopodobniej oznaczało życie zgodne $\mathrm{z}$ ascetycznym ideałem całkowitego poświęcenia się służbie Bożej.

Teologia „prymatu Piotra” w pismach Afrahata i św. Efrema jest wyraźnie chrystocentryczna, nie brak w niej także wątków pneumatologicznych. Obaj Syryjczycy wykorzystują materiał biblijny, komentując obrazy i sytuacje, w których Pismo św. mówi o Szymonie Piotrze. Zwłaszcza w komentarzach Efrema widoczne jest wyraźne akcentowanie idei pełnomocnictwa władzy Piotrowej. Wyjątkowa pozycja świętego Apostoła wynika z faktu, iż wybrał go Chrystus: jedyny Fundament, Głowa i Pasterz Kościoła.

Ta krótka analiza problemu pozycji świętego Piotra pozwoliła uświadomić sobie ciągle realne niebezpieczeństwo poprawności apologetycznej w metodologii badaniach naukowych. W podsumowaniu można przyjąć, iż w pismach Afrahata i Efrema mówienie o prymacie św. Piotra polega na akcentowaniu wyjątkowości jego pozycji i ogranicza się tylko do jego osoby bez jakichkolwiek konsekwencji i aluzji do następców.

\title{
LA POSITION DE SAINT PIERRE DANS LES SUVRES D'APHRAHAT LE SAGE PERSAN ET DE SAINT EPHREM LE SYRIEN
}

\author{
(Résumé)
}

L'auteur de cet article relève le problème peu élaboré dans la littérature patristique d'aujourd'hui. Il s'agit d'une réflexion sur le sujet de la position de saint Pierre dans les œuvres d'Aphrahat le Sage Persan et de saint Ephrem le Syrien. Une courte analyse de ce thème nous permet de constater d'abord que les résultats des recherches d'autrefoi dévoilent l'influence d'une tendance apologétique très forte. Dans leurs commentaires des paraboles et des images biblique Aphrahat et Ephrem scrutent les motifs de la vocation et les dévoirs de la responsabilité de Pierre. Il en résulte que sa position particulière, disons primat, parmi les Apôtres ne concerne que sa persone. 